\title{
INFORMACIJA
}

\section{PARLAMENTARŲ INFORMACINIS APRŪPINIMAS - DEMOKRATIJOS PLÉTROS INSTRUMENTAS}

DR. Regina VARNiENĖ-JaNSSEN

Lietuvos nacionalinè Martyno Mažvydo biblioteka Martynas Mažvydas National Library of Lithuania Gedimino pr. 51, 01504 Vilnius El.paštas r.varniene@lnb.lt

Aurelija Vernickaité

Vilniaus universiteto Komunikacijos fakultetas doktorante Vilnius University Faculty of Communication, Ph. D. Candidate Sauletekio al. 9, 10222 Vilnius

El.paštas aurelija.vernickaite@kf.stud.vu.lt

„Protingos organizacijos pripažịsta informaciją kaip svarbiausią mūsų epochos turtą"

(Taylor, 1996)

\section{Santrauka}

Vieningos ir atviros Europos kūrimo kontekste ypač aktuali valdžios aprūpinimo informacija ir jos atvirumo problema, nes nuo informacinio aprūpinimo kokybès priklauso valdžios instituciju priimamu sprendimu kokybė.

Šioje publikacijoje nagrinejamas informacijos vaidmuo sprendimu priemimui, apžvelgiami vykdyti tyrimai apie parlamentaru informacinius poreikius ir ju aprūpinima informacija, supažindinama su Lietuvos parlamentaru informacinio aprūpinimo būkle. 
Reikšminiai žodžiai: informaciniai poreikiai; sprendimų prièmimas; informacinis aprūpinimas; parlamentinè biblioteka.

\section{İvadas}

2000 m. Europos Vadovų Taryba Lisabonoje patvirtino strategiją, kurioje ivardyta Europos Sajungos vizija - „konkurencingiausia ir dinamiškiausia žiniomis grịsta ekonomika pasaulyje, gebanti tvariai ekonomiškai plètotis sukuriant daugiau ir geresnių darbo vietų ir stiprinti socialinę sanglaudą".

Viena iš prioritetinių Strategijos krypčių yra europinio turinio plètra ir prieiga globaliuose tinkluose, išnaudojant visas skaitmeninių technologijų galimybes, ir bendros Europos informacijos erdvès, leidžiančios igyvendinti vieningos Europos idejją, sukūrimas. Vieningos Europos strategija grindžiama prieigos prie valstybinès vidaus ir tarptautinès informacijos principais: užtikrinti visiems lygias prieigos prie informacijos galimybes; šalyje sukurtą informaciją traktuoti valstybės turtu ir prisiimti atsakomybę už jos ilgalaikị išsaugojimą ir sklaidą; siekti valdžios institucijų atvirumo; užtikrinti šių institucijų informacijos sklaidą.

Vieningos ir atviros Europos kūrimo kontekste ypač aktuali valdžios aprūpinimo informacija ir jos atvirumo problema, nes nuo informacinio aprūpinimo kokybės priklauso valdžios institucijų priimamų sprendimų kokybè. Tinkamas aprūpinimas informacija leidžia įstatymų leidejams veiksmingiau atlikti savo funkcijas svarbiausiose - teisèkūros ir parlamentinès kontrolès - srityse. Ekspertinès žinios, nepriklausoma ir objektyvi informacija užtikrina efektyvius ir laiku priimamus įstatymų leidžiamosios valdžios sprendimus.

Valdžios atvirumo ir aiškumo poreikis atsirado po Mastrichto sutarties. Buvo suvokta, kad stiprëjant Europos Sąjungos vidiniams ryšiams, priimant vis daugiau tarpvalstybinio lygmens sprendimų, augs Europos visuomenès poreikis žinoti apie ES tikslus ir strategiją. Tai paskatino Eu-

1 Prieiga per internetą: $<$ http://www.ukmin.lt/lt/strategija/doc/n-lis.pr.-2005-11-22,nr.1270.doc > 
ropos Komisiją priimti reikšmingus strateginius komunikatus dèl europinio turinio skaitmeninès erdvès sukūrimo.

Atvirumo sąvoka sprendimų prièmimo procese yra naudinga ir valdžios institucijoms, ir jos rinkejams. Pagrindinis motyvas, kuriuo remiamasi Europos Sąjungoje realizuojant valdžios atvirumo ideją - kuo geriau piliečiai bus informuoti apie valdžios institucijų priimamus sprendimus, tuo demokratiškesnès bus ir ES institucijos. Tai savo ruožtu daro ịtaką rinkèjų pasitikèjimui valdžios institucijomis. Siekdama šio pasitikejjimo valdžia turi būti pasiruošusi paaiškinti savo vykdomų strategijų ir priimamų sprendimų pagrịstumą. Todèl būtina teikti informaciją dviem kryptimis: informaciją, padedančią sprendimų prièmëjams formuoti strategijas, ir informaciją, padedančią visuomenei susipažinti su strateginiais sprendimais ir užtikrinančią, kad visuomenė gerai tuos sprendimus suprastų.

Kadangi šalių ir tautų raida yra pernelyg skirtinga ir nevienalaikè, tai ir informacinès sistemos, aprūpinančios sprendimų prièmèjus ir visuomenę, yra skirtingos. Kiekvienoje šalyje šios sistemos turi savo ypatumų. Senosiose demokratijos šalyse jau ịsitvirtinusi „žiniatinklio visuomenë“ apima vis platesnius socialinius sluoksnius rinkẻjų, kurie kaskart vis aktyviau įsitraukia ị šalies politikos procesus. Šiame kontekste informacijos sklaidos institucijos ar jų padaliniai, teikiantys paslaugas įstatymų leidžiamiesiems organams, yra ypač svarbūs socialinès integracijos procese. Jie turi galimybę teikti interaktyvias elektronines paslaugas, skleisti svarbią informaciją plačiajai visuomenei, taip pat siūlyti tiesioginès komunikacijos su politiniais atstovais būdus. Šių technologijų plètra sudarè sąlygas atsirasti naujoms komunikacijos priemonėms ir lèmé kai kuriuos svarbius socialinius pokyčius tokiose srityse kaip lyčių klausimai, aplinkosauginis sąmoningumas ir net politinè sistema. Informacinès technologijos, jei prie jų suteikiama plati prieiga, pajègios daryti itaką didžiajai daliai žmogaus veiklos sričių.

Kokie šio proceso ypatumai Lietuvoje? Kokios išskirtinès šio potencialo savybès - tiek teigiamos, prisidedančios prie istatymų leidèjų sprendimų prièmimo bei įtraukiančios vis platesnius visuomenès 
sluoksnius $\mathfrak{i}$ šalies politikos procesus, tiek ir neigiamos, didinančios atskirtị tarp visuomenès ir politikos?

Šioje publikacijoje daugiausia nagrinejjamas informacijos vaidmuo sprendimų prièmimui, apžvelgiami vykdyti tyrimai apie parlamentarų informacinius poreikius ir jų aprūpinimą informacija, supažindinama su Lietuvos parlamentarų informacinio aprūpinimo būkle.

\section{Informacijos vaidmuo sprendimų prièmimo procese}

Politikų centrinė veiklos ašis yra sprendimų prièmimas. Sprendimų prièmimą galima apibrèžti kaip procesą, kuriam vykstant pasirenkama alternatyva arba tam tikrai alternatyvai suteikiama preferencija. Sprendimų prièmimo procesas apibrèžiamas kaip „informacijos virtimas veiksmu“, taip pabrěžiant informacijos svarbą šiame procese ${ }^{2}$. Informacija yra būtina ir aktuali kiekvienam visuomenès nariui, neabejotinai - ir ịstatymų leidèjams, kurių priimami isstatymai, norminiai aktai reguliuoja svarbiausius visuomeninius santykius. Informacija, kuria naudojasi ir kuri yra prieinama parlamentarams, lemia jų priimamų sprendimų kokybę. Neturẻdami pakankamai informacijos politikai rizikuoja priimti neteisingus, daug kainuojančius ir net visuomenei pavojingus sprendimus. ${ }^{3}$

Informacijos ir žinių svarbą politiniuose sprendimo prièmimo procesuose teoretikai pagrindè jau prieš keletą dešimtmečių. Ronai ir Bryanto tyrimas atskleidè, kad stiprios demokratijos kertinis akmuo yra efektyvi ir nepriklausoma įstatymų leidžiamoji valdžia, kuri pirmiausia turi būti gerai informuota ${ }^{4}$. Anot Zawislako, sprendimų priemimų kokybė priklauso

2 Parsons, W. Viešoji politika: politikos analizès teorijos ir praktikos ł̇vadas. Vilnius: Eugrimas, 2001, p. 543.

3 Alemna, A.A., Skouby, K.E. An investigation into the information needs and information seeking behaviour of Members of Ghana's Legislature [interaktyvus]. Library Management. 2000, vol. 21, p. 235-40 [žiūrèta 2010-01-12]. Prieiga per internetą: $<$ http://www. emeraldinsight.com/Insight/viewPDF.jsp?contentType=Article\&Filename $=$ html/Output/ Published/EmeraldFullTextArticle/Pdf/0150210502.pdf $>$

4 Ronai, I., Bryant, M.N. The role of Hungary's Parliamentary Library in fostering democratic decision making. Libri. 1992, vol. 42, No. 2, p. 136-43. 
nuo parlamentarų naudojamos informacijos kokybès. Sprendimų prièmèjai informaciją, gaunamą iš patikimo šaltinio, naudoja dažniau ${ }^{5}$. Barkeris ir Rushas teigè, kad „politikai yra visuomenès problemų advokatai ir jie naudoja ịvairią informaciją, kad pagrịstų tas problemas“6.

Informacijos vaidmeni sprendimų prièmimo procese atskleidžia mokslininkų sukurti modeliai. Jenkinso ir Laswello ${ }^{7}$ sukurtuose septynių etapų sprendimų prièmimo proceso modeliuose pabrèžta informacijos svarba (1 ir 2 pav.).

Iniciacija

Informacija

Svarstymas

Sprendimas

Igyvendinimas

Ivertinimas

Baigtis

1 pav. Jenkinso sprendimu priemimo modelis
Informacija

Propagavimas

Itikinejjimas

Isakymas

Taikymas

Baigtis

Ivertinimas

2 pav. Laswello sprendimy

priemimo modelis

Naudingos, tikslios ir laiku gaunamos informacijos poreikis priimant sprendimus augo kartu su demokratija. Kuo daugiau su šiuolaikine visuomene susijusių klausimų tampa ịstatymų leidžiamosios valdžios objektais, tuo daugiau žinių reikia parlamentarams, kad galètų priimti teisingus sprendimus tose srityse, apie kurias mažai išmano. Tačiau kuo labiau daugejja problemų, temų ir objektų, su kuriais susiduria parlamentarai, tuo

5 Iš Marcella, R., Baxter, G. The information needs of United Kingdom Members of the European Parliament. Library management. 1999, vol. 20, p. 168-178. Prieiga per interneta: $<$ http://www.emeraldinsight.com/Insight/viewContentItem.do?contentType=Articl e\&hdAction $=1$ nkpdf\&contentId=858924>

6 Barker, A., Rush, M. The Member of Parliament and his information. 1970.

${ }^{7}$ Iš Parsons, W. Viešoji politika: politikos analizès teorijos ir praktikos juvadas. Vilnius: Eugrimas, 2001, p. 543. 
labiau auga reikalingos informacijos kiekis. Jam didejant susiduriama su informacijos perkrovos (information overload) problema. ${ }^{8}$

Šiuolaikiniams parlamentams keliami demokratiškumo, atskaitingumo, gebejjimo reaguoti ị sudètingas ekonomines, teisines ir kt. problemas reikalavimai. Argumentuotus, efektyvius ir laiku parengtus parlamentų sprendimus užtikrina ekspertinės žinios ir nepriklausoma informacija, kuria disponuoja patys parlamentai. Parsonso teigimu, svarbu atskirti informaciją, kuri yra susijusi su valdžia - gaunama iš vidinių šaltinių arba kuriama jos užsakymu, ir kuri egzistuoja nepriklausomai nuo valdžios. ${ }^{9}$ Sprendimų prièmimo procese naudojamą informaciją Parsonsas suskirste i keturis kvadrantus (3 pav.).

\begin{tabular}{|l|l|}
\hline 1 & 2 \\
Departamentiniai tyrimai & Komisijos \\
Vidaus mokslinių grupių (angl. think tank) & Tyrimų komitetai \\
pranešimai & Teismų ap̌̌valgos \\
Vidaus ekspertų pranešimai & İstatymų leidejų pranešimai \\
& Užsakomieji tyrimai \\
& Formalios (oficialios) kon- \\
sultacijos
\end{tabular}

3 pav. Valdžios informacijos šaltiniai (Parsons, 1995)

8 Marcella, R., Baxter, G. The information needs of United Kingdom Members of the European Parliament. Library management. 1999, vol. 20, p. 168-178. Prieiga per internetą: $<$ http://www.emeraldinsight.com/Insight/viewContentItem.do?contentType=Article \&hd Action=lnkpdf\&contentId=858924>

9 Parsons, W. Viešoji politika: politikos analizès teorijos ir praktikos juvadas. Vilnius: Eugrimas, 2001, p. 543. 
Pirmajame kvadrante yra tik vidinių šaltinių informacija, ji gali būti vieša arba ne. Antrajame kvadrante - informacija, igyjama iš išorinių šaltinių. Trečiajame kvadrante - neformaliose diskusijose su ekspertais ar interesų grupėmis gauta informacija. Ketvirtajame kvadrante - neformaliose valdžios atstovų diskusijose gauta informacija.

Sprendimų prièmejjams labai svarbu gauti ir ịvertinti informaciją iš ivvairių šaltinių tam, kad būtų priimtas pats geriausias sprendimas: opozicija gali labiau vertinti informaciją, gautą iš šaltinių, nepriklausančių nuo vyriausybès, valdantieji gali labiau pasitikèti ne išorinių, o vidinių šaltinių informacija. ${ }^{10}$ Anot tyrèjų, kuo turtingesnè visuomenè, tuo daugiau alternatyvų centrinès valdžios pateiktai informacijai gali gauti parlamentarai. ${ }^{11}$ Rinkejjai iš politikų tikisi daugelio visuomenei aktualių klausimų žinojimo/išmanymo, todèl parlamentarai privalo būti efektyvūs informacijos rinkejjai ir vadybininkai, gebantys lanksčiai ieškoti informacijos ir kritiškai įvertinti informacijos šaltinius. ${ }^{12}$

\section{Parlamentarų informacinių poreikių ir jų aprūpini- mo informacija tyrimai}

Siekiant kokybiško ir efektyvaus parlamentarų informacinio aprūpinimo, būtina žinoti parlamentarų informacinius poreikius, suprasti jų informacinę elgseną, informacijos naudojimą. Šiame skyriuje bus apžvelgti užsienyje atlikti moksliniai tyrimai, nes Lie-

${ }^{10}$ Marcella, R., Baxter, G. The information needs of United Kingdom Members of the European Parliament. Library management. 1999, vol. 20, p. 168-178. Prieiga per internetą: $<$ http://www.emeraldinsight.com/Insight/viewContentItem.do?contentType=Article \&hd Action $=$ lnkpdf\&contentId $=858924>$

${ }^{11}$ Tanfield, J. Parliamentary Library, Research and Information services of Western Europe [interaktyvus]. 1993. Prieiga per interneta: $<$ https://ecprd.secure.europarl.europa.eu/ecprd/ getfile.do?id=5065>

${ }^{12}$ Orton, R., Marcella, R., Baxter, G. An observational study of the information seeking behaviour of the Members of Parliament in the United Kingdom [interaktyvus]. Aslib Proceedings. Vol. 52, p. 787-97 [žiūrèta 2010-01-15]. Prieiga per internetą: < http://www. emeraldinsight.com/Insight/viewPDF.jsp? contentType $=$ Article $\&$ Filename $=$ html/Output/ Published/EmeraldAbstractOnlyArticle/Pdf/2760520602.pdf > 
tuvoje panašaus pobūdžio mokslinių tyrimų nebuvo atlikta. Tačiau prieš apžvelgiant tyrimus, susijusius su parlamentarų informacine elgsena, poreikiais, informacijos naudojimu, reikètų priminti, kad informacinè elgsena $\mathfrak{i}$ mokslininkų tyrimų lauką pateko praejjusio amžiaus 6-ajame dešimtmetyje. Iš pradžių informacijos vartotojas nebuvo tų tyrimų objektas ${ }^{13}$, tyrimai rémési statistiniais metodais: skaičiuoti bibliotekų ir informacinių centrų lankytojai, apsilankymų skaičius, naudojami informacijos šaltiniai. ${ }^{14}$ Todèl nenuostabu, kad ir pirmieji tyrimai buvo orientuoti i parlamentinių bibliotekų paslaugas, informacines sistemas. Pirmieji tyrinèti parlamentarų informacinị aprūpinimą èmèsi britų mokslininkai Bakeris ir Rushas. Studijoje „Parlamento narys ir jo informacija“ jie teigè, kad informacijos gavimo laikas yra svarbiausias veiksnys, kuri vertina parlamentarai informacijos paieškos procese; papildomos informacijos poreikis - analitinių apžvalgų ar pranešimų - dažniausiai kyla mažiau patirties turintiems parlamentarams. ${ }^{15}$ Atlikta nemažai tyrimų, susijusių su Didžiosios Britanijos Bendruomenių rūmų bibliotekos vaidmeniu aprūpinant parlamento narius informacijos ir jos paslaugų kokybės vertinimu. Didžiosios Britanijos mokslininkai tyrinejjo problemas, su kuriomis susiduria Bendruomenių rūmų biblioteka siekdama patenkinti skirtingus parlamentarų ir visuomenès poreikius, tinklo POLIS (Parliamentary Online Information System) ir kompiuterių naudojimą parlamentineje bibliotekoje, internetinę paiešką joje, lygino skirtingų šalių parlamentinių bibliotekų darbą.

Vèliau atsirado tyrimų, kuriuose vertinta parlamentinès bibliotekos paslaugų kokybė ir jų atitiktis parlamentarų informaciniams

${ }^{13}$ Mutshewa, A. A theoretical exploration of information behaviour: a power perspective. [interaktyvus]. Aslib Proceedings. Vol. 59, p. 249-263 [žiūrèta 2010-01-14]. Prieiga per internetą: $<$ http://www.emeraldinsight.com/Insight/viewPDF.jsp?contentType=Article \& Filename $=$ html/Output/Published/EmeraldFullTextArticle/Pdf/2760590304.pdf $>$

${ }^{14}$ Wilson, T.D. On user study and information need. Journal of Documentation. 1981, vol. 37, No. 1, p. 3-15.

${ }^{15}$ Barker, A., Rush, M. The Member of Parliament and his information. 1970. 
poreikiams. Tyrimai atskleidè, kad parlamentinė biblioteka yra pagrindinis informacijos šaltinis įstatymų leidejjams ir jų personalui. Informaciją gaudami ir iš kitų šaltinių - vyriausybès, profsąjungų ir kitų interesų grupių, parlamentinès bibliotekos informaciją istatymų leidejjai vertino kaip greičiausiai pateikiamą ir objektyviausią/nešališkiausią. ${ }^{16}$

Marcella ir Baxter tyrinejo Didžiosios Britanijos atstovų Europos Parlamente požiūrị ị informacijos vaidmenị jų darbe, gebejjimus identifikuoti, rasti ir ịvertinti informaciją, kuri labiausiai atitinka poreikius. Tyrimas atskleide kelias pagrindines problemas, su kuriomis susiduria ịstatymų leidejjai: labai ịvairios ir skirtingos informacijos poreikis; pradinių žinių îvairiais klausimais trūkumas; poreikių nenuspejjamumas; poreikis gauti informaciją greitai; poreikis ugdyti daugianacionalinị supratimą; informacijos - oficialios ir neoficialios - kiekio augimas; negebejimas naudotis naujomis prieigomis prie informacijos. ${ }^{17}$ Tais pačiais metais atliktas kitas tyrimas apie Didžiosios Britanijos Bendruomenių rūmų bibliotekos informacines paslaugas ir parlamentarų poreikius atskleidè, kad ši biblioteka parlamentarams yra pagrindinis ir būtinas informacijos šaltinis, o jos teikiamos paslaugos atitinka parlamentarų informacinius poreikius. ${ }^{18}$ Didžiosios Britanijos parlamentarų informacinès elgsenos tyrimai parodè, kad parlamentarai naudojasi

${ }^{16}$ Orton, R., Marcella, R., Baxter, G. An observational study of the information seeking behaviour of the Members of Parliament in the United Kingdom [interaktyvus]. Aslib Proceedings. Vol. 52, p. 787-97 [žiūrèta 2010-01-15]. Prieiga per internetą: < http://www. emeraldinsight.com/Insight/viewPDF.jsp? contentType $=$ Article $\&$ Filename $=$ html/Output/ Published/EmeraldAbstractOnlyArticle/Pdf/2760520602.pdf>

${ }^{17}$ Marcella, R., Baxter, G. The information needs of United Kingdom Members of the European Parliament. Library management. 1999, vol. 20, p. 168-178. Prieiga per internetą: $<$ http://www.emeraldinsight.com/Insight/viewContentItem.do?contentType=Article \&hd Action $=1$ nkpdf\&contentId=858924>

${ }^{18}$ Serema, B. Matching MPs' information needs and information services in the House of Commons [interaktyvus]. Library Management. 1999, vol. 20, p. 179-189 [žiūrèta 2010-01-14]. Prieiga per internetą: <http://www.emeraldinsight.com/Insight/viewPDF. jsp? contentType $=$ Article $\&$ Filename $=$ html/Output $/$ Published/EmeraldFullTextArticle $/$ Pdf/0150200304.pdf > 
ivvairiais informacijos šaltiniais, tačiau informacijos ištekliai taip pat kelia nemažų problemų. ${ }^{19}$

Ganos Respublikos įstatymų leidejjų informacinį aprūpinimą tyrę mokslininkai atskleide, kad labiausiai parlamentarams informacijos reikia ruošiantis diskusijoms; jie menkai naudojasi elektroniniais informaciniais ištekliais, o parlamentinès bibliotekos paslaugomis nèra visiškai patenkinti. Alemna ir Skuby pabrèžè, kad siekiant našesnio parlamentarų darbo ypač svarbu kuo geriau suprasti parlamentarų informacinius poreikius, nes kuo daugiau temų ịtraukiama ị ístatymų leidèjų darbotvarkę, tuo daugiau informacijos privalo turèti parlamentarai, kad galètų priimti sprendimus tose srityse, apie kurias iš tiesų turi mažai pradinių žinių. ${ }^{20}$

Mostertas ir Ocholla tyrinejjo Pietų Afrikos parlamentarų informacinius poreikius ir informacinę elgseną. Freidinas aiškinosi, kaip Izraelio parlamentarai aprūpinami informacija. Empirinis tyrimas atskleidè, kad ìstatymų leidejams trūksta objektyvios ir patikimos informacijos, kuri padètų priimti sprendimus. Abu šie tyrimai parodè, kad parlamentarai dažnai informacijos ieško ne patys, o per trečiuosius asmenis - bibliotekininkus, mokslininkus, asmeninius patarejus. ${ }^{21}$

Shailendra ir Prakashas teigia, kad parlamentarų poreikiai dažnai yra nenuspejami. Jiems reikia einamosios/retrospektyvinès, patikimos, naudingos ir išsamios informacijos, tačiau tokia informacija nèra efektyviai aprūpinami. Shailendros ir Prakasho tyrimas atskleidè, kad daugu-

${ }^{19}$ Orton, R., Marcella, R., Baxter, G. An observational study of the information seeking behaviour of the Members of Parliament in the United Kingdom [interaktyvus]. Aslib Proceedings. Vol. 52, p. 787-97 [žiūrèta 2010-01-15]. Prieiga per internetą: < http://www. emeraldinsight.com/Insight/viewPDF.jsp?contentType=Article\&Filename $=$ html/Output/ Published/EmeraldAbstractOnlyArticle/Pdf/2760520602.pdf>

${ }^{20}$ Alemna, A.A., Skouby, K.E. An investigation into the information needs and information seeking behaviour of Members of Ghana's Legislature [interaktyvus]. Library Management. 2000, vol. 21, p. 235-40 [žiūrèta 2010-01-12]. Prieiga per internetą: $<$ http://www. emeraldinsight.com/Insight/viewPDF.jsp?contentType $=$ Article \&Filename $=$ html/Output $/$ Published/EmeraldFullTextArticle/Pdf/0150210502.pdf>

${ }^{21}$ Freidin, H. The information requirement of Israeli parliamentarians (Knesset Members): findings of a survey. Information and Librarianship. 1993, vol. 20, No. 1, p. 11-14. 
ma Delio (Indija) İstatymų Leidžiamojo Susirinkimo narių nesinaudoja elektroniniais informacijos šaltiniais - internetu, intranetu ir kt. Nors parlamentine biblioteka yra svarbus informacijos šaltinis, politikai nesinaudoja daugeliu jos paslaugų, nes apie jas nežino arba neturi laiko jomis naudotis. ${ }^{22}$

Mokslininkai taip pat tyrinejjo Ugandos parlamentarų informacinę elgseną. Atskleista, kad nors vyrų ir moterų aprūpinimo informacija sąlygos parlamente yra vienodos, socialinis ir politinis kontekstas lemia, kad moterys susiduria su daugiau informacinių barjerų. ${ }^{23}$

Tuominen ir Turja analizavo socialinès mokslinès informacijos naudojimą parlamentinèse diskusijose. Šia informacija dažniausiai remiamasi norint išspręsti tam tikrą socialinę problemą, pateikti statistinius irodymus, parodyti priežastinius ryšius ar pagrịsti argumentus. Tačiau nustatyta, kad socialinès informacijos objektyvumas ir autoritetingumas parlamentinèse diskusijose gali būti pakirstas panaudojant mažiausiai keturių tipų argumentus: paneigimus, informacijos politizavimą, informacijos netikrumą ir mokslinių žinių negebejjimą spręsti vertybinius konfliktus. $^{24}$

\section{Parlamentinès bibliotekos samprata}

2008 m. Ženevoje (Šveicarijos Konfederacija) vyko tarptautinė konferencija, skirta pateikti parlamentinių bibliotekų veiklą. Akcentuota, kad šių bibliotekų reikalingumas auga, nes jos prisideda prie parlamentarų

${ }^{22}$ Shailendra, K., Prakash, H. (2007). A study of information needs of Members of the Legislative Assembly in the capital of India [interaktyvus]. Aslib Proceedings: New Information Perspectives. 2008, vol. 60, p. 158-159 [žiūrèta 2010-01-12]. Prieiga per internetą: $<$ http://www.emeraldinsight.com/Insight/viewPDF.jsp?contentType=Article \& Filename=html/Output/Published/EmeraldFullTextArticle/Pdf/2760600206.pdf $>$

${ }^{23}$ Nalumaga, R. Crossing to the mainstream: information challenges and possibilities for female legislators in the Ugandan Parliament [interaktyvus]. 2009. Doctoral thesis. Prieiga per interneta: < http://bada.hb.se/handle/2320/5356>

${ }^{24}$ Tuominen, K., Turja, T. Use of social scientific information in parliamentary discussions. Advance in Library Administration and Organization. 2007, vol. 25, p. 133-154. 
darbo efektyvumo - aprūpina autoritetinga, nepriklausoma ir nešališka informacija. ${ }^{25}$ Augant informacijos srautams ją galima atsirinkti pasitelkus įvairias paieškos sistemas ir kitus šaltinius, tačiau dažnai tokiu būdu pateikiant informaciją siekiama formuoti tam tikrą nuomonę ir pakreipti ịstatymų leidejų veiksmus viena ar kita kryptimi. Todèl informacija iš patikimo šaltinio turi papildomą vertę. Kaip minèta ankstesniame skyriuje, parlamentarams labai svarbu nepriklausyti nuo vieno informacijos šaltinio - vyriausybès, galimybès vykdyti vykdomosios valdžios kontrolę ir užtikrinti pusiausvyrą tarp leidžiamosios ir vykdomosios valdžių.

Istoriškai pagrindinès parlamentinès bibliotekos funkcijos buvo dokumentų kaupimas, katalogavimas, saugojimas, tačiau dabar parlamentinè biblioteka suprantama kaip kur kas daugiau nei dokumentų saugykla ir jų išdavimas. Parlamentinès bibliotekos teikia daugelị informacinių paslaugų: atsako ị užklausas, kuria ịstatymų duomenų bazes, teikia bibliografinę informaciją.

Daugelyje šalių istoriškai susiklostè, kad parlamentarams šias paslaugas teikia parlamentuose susikūrusios tradicinès bibliotekos ir/ar mokslo tiriamieji centrai ir nacionalinès bibliotekos, kurios atlieka ir parlamentinès bibliotekos funkcijas. Šių institucijų teikiamos paslaugos per daugeli jų gyvavimo metų tobulejo ir vystėsi veikiant politiniams, ekonominiams bei informacinių technologijų plètros veiksniams. Paskutiniaisiais dešimtmečiais ypač išaugo poreikis labiau sofistikuotų informacinių paslaugų, tokių kaip ekspertinė analizė ar informacijos sintezè. Tai siejama su informacijos perkrovos reiškiniu. Pastebima, kad nesudètingų informacinių užklausų skaičius mažejja, o didejja sudètingų analitinių tyrimų paklausa ir elektroninių informacijos šaltinių ir laikmenų poreikis. Technologinè pažanga lèmè tai, kad kito ne tik informacijos ir žinių aplinka, bet ir pačių parlamentarų poreikiai ir lūkesčiai. Tai verčia bibliotekas modernizuoti darbo metodus.

${ }^{25}$ Informing democracy: building capacity to meet parliamentarians ' information and knowledge needs. Ifla Reports and documents. 2008, No. 59. 
Šiuo metu Europoje ir visame pasaulyje vis plačiau kalbama apie fundamentinius pokyčius politikos informacinio aprūpinimo srityje. Mokslinèje ir specialiojoje literatūroje, skirtoje parlamentarų informaciniam aprūpinimui, šiuo metu ryškejja tokios inovacijų tendencijos:

- Problemiškai orientuotų informacijos produktų ir paslaugų kūrimas;

- Visateksčių dokumentų kūrimas ir jų panaudojimo plètra;

- Naujausių paieškos galimybiu - Web. 2.0 ir semantinio Web diegimas ir parlamentarų apmokymas;

- Parlamentarizmo stebėsenos sistemos kūrimas.

Viena vertus, išvardytos inovacijų kryptys reiškia iš esmès naujų informacinių paslaugų sukūrimą. Kita vertus, jas galima traktuoti kaip jau vykdomų informacinių paslaugų pateikimą naujais būdais, pavyzdžiui, pateikiant skaitmenines knygas, žurnalus, pranešimus vietoj tradicinès formos dokumentų. Tai savo ruožtu pagreitina informacinị aprūpinimą bei pagerina jo efektyvumą. Išvardytų inovacijų kontekste apžvelgsime Lietuvos parlamentarų aprūpinimą informacija ir žiniomis.

\section{Lietuvos parlamentary informacinio aprūpinimo sistema}

Lietuvos parlamentarų informacinis aprūpinimas nebuvo išsamiau aptariamas mokslinèje literatūroje, ǐ̌skyrus vos keletą publikacijų informaciniuose leidiniuose. ${ }^{26}$ Tai tik patvirtina šios temos aktualumą ir reikalingumą.

Lietuvos parlamentarų informacinị aprūpinimą šiuo metu vykdo dviejų istaigu - Lietuvos Respublikos Seimo kanceliarijos ir Lietuvos nacionalinès Martyno Mažvydo bibliotekos (toliau - Nacionalinè bibliote-

${ }^{26}$ Blagniene, R. The Information Analysis Department of Lithuanian Seimas. Parliamentary libraries and research services in Central and Eastern Europe : building more effective legislatures. 1998, X, p. 108-113. 
ka), vykdančios ir parlamentinès bibliotekos funkcijas, darbuotojai, kurie naudojasi šių institucijų informaciniais ištekliais ir informacinèmis sistemomis - Seimo informacine sistema ir Lietuvos integralia bibliotekų informacijos sistema, įdiegta per 80 šalies bibliotekų.

Po nepriklausomybės paskelbimo $1990 \mathrm{~m}$. Seimo kanceliarijoje buvo nedidelis informacijos skyrius, biblioteka ir spaudos biuras. $1993 \mathrm{~m}$. reorganizavus Seimo kanceliariją, ịkurtas Informacijos ir analizès tarnybų padalinys, kurị sudarè Informacijos analizès skyrius, atsakingas už informacijos kaupimą, analizę ir platinimą, bei Spaudos ir viešųjų ryšių skyrius, atsakingas už parlamento veiklos viešinimą. 2007 m. patvirtinus naują Seimo kanceliarijos struktūrą, Informacijos analizès skyrius reorganizuotas ị Parlamentinių tyrimų departamentą. Šis departamentas bendradarbiauja su Nacionaline biblioteka, kuriai 1991 m. lapkričio 20 d. Aukščiausiosios Tarybos Prezidiumo nutarimu pavesta vykdyti parlamentinès bibliotekos funkcijas. Atsiradus šiai funkcijai, buvęs specializuotas Nacionalinès bibliotekos Vyriausybinių organizacijų aptarnavimo skyrius pertvarkytas ì Vadovybès informacijos skyrių, kurio paskirtis - bibliografinès informacijos teikimas Seimui ir vykdomosios valdžios institucijoms.

\subsection{Seimo informacinè sistema parlamentarų informaciniams po- reikiams tenkinti}

Parlamentinių tyrimų departamentas - informacines, analitines ir bibliotekines paslaugas teikianti parlamento kanceliarijos struktūra. Seimo kanceliarijos strateginiame veiklos plane ịrašyta, jog parlamentarus aprūpinant ekspertiniais ir informaciniais ištekliais siekiama, „kad šios paslaugos būtų profesionalios, tinkamos kokybės, teikiamos teisès aktų nustatyta tvarka ir terminais. Teikiamos paslaugos turi sudaryti sąlygas kurti ir plètoti teisinès demokratinès valstybès principu pagrịstą teisès sistemą ir užtikrinti veiksmingą valstybès institucijų parlamentinę kontrolę “.27

${ }^{27}$ Lietuvos Respublikos Seimo kanceliarijos 2009-2011 strateginis veiklos planas. Prieiga per internetą: <http://www3.1rs.1t/docs2/NASSCHIO.PDF> 
Parlamentinių tyrimų departamentą sudaro 4 skyriai:

- Ekonominès ir socialinès informacijos skyrius;

- Bibliografinès informacijos skyrius;

- Bendrosios informacijos skyrius;

- Teisinès ir politinès informacijos skyrius.

Departamentas atsakingas už Seimo informacijos vartotojams ịstatymų leidybos ir kitos Seimo veiklos užtikrinimui reikalingos informacijos kaupimą, apdorojimą, teikimą ir jos analizę; Seimo nariams ir Seimo kanceliarijai reikalingų dokumentų komplektavimą; informacinès sistemos, leidžiančios panaudoti sukauptus informacijos išteklius, kūrimą. Parlamentinių tyrimų departamento informacinė sistema skirta rengti ir kaupti analitinėms apžvalgoms apie Seimo darbą, pateikti žiniasklaidos ir ekspertų vertinimus, visuomenès atsiliepimus apie Seimo darbą.

Parlamentinių tyrimų departamentas aptarnauja tik Seimo narius ir Seimo kanceliarijos darbuotojus, nes taip siekiama užtikrinti šio padalinio veiklos nepriklausomumą ir nešališkumą. ${ }^{28}$ Visi Parlamentinių tyrimų departamento atlikti darbai skelbiami vidineje intraneto svetaineje ir prieinami tik Seimo nariams ir Seimo kanceliarijos darbuotojams.

Departamento Teisinès ir politinès bei Ekonominès ir socialinès informacijos skyriai tiek Seimo informacijos vartotojų, tiek savo iniciatyva rengia analitinius tyrimus teisèkūros, parlamentinès kontrolès, viešosios politikos ir kt. aktualiais klausimais. Taip pat yra teikiama susisteminta informacija apie konkrečių Seimo sesijų prioritetus, po sesiju - parlamento veiklos teisèkūros srityje rezultatai. Bendrosios informacijos skyrius rengia kasdienes ir savaitines Lietuvos ir užsienio spaudos apžvalgas: „Užsienio naujienų santrauka“, „Užsienio spauda

${ }^{28}$ Seimo kanceliarijos metinè veiklos ataskaita. 2009. Prieiga per internetą: <www3.1rs.1t/ home/ataskaitos/Seimo_kanceliarija_atskaita2009.pdf> 
apie Baltijos valstybes“, „Svarbesni ELTA ir BNS agentūrų pranešimai“, „Televizijos naujienų santrauka“. Taip pat rengiami specializuoti savaitiniai teminiai leidiniai tam tikrais aktualiais klausimais, pavyzdžiui, „Pasaulinė ekonomikos ir finansų krizė: pranešimų santrauka“. Skyriuje apdorojama ir kaupiama garso ir vaizdo informacija, sukurti jų archyvai.

Bibliografinès informacijos skyrius atsakingas už dokumentų komplektavimą, tvarkymą ir išdavimą, rengia spaudos apžvalgas apie Seimo ir Seimo kanceliarijos darbą, atsako ị bibliografines, temines ir faktografines užklausas. Bibliografinès informacijos skyriuje sukaupta daugiau nei 21000 knygu teisès, politikos, ekonomikos, istorijos ir kt. mokslų klausimais. Šis skyrius taip pat atlieka ir tradicinės bibliotekos paslaugas - skaitytojai gali skolintis knygas ir periodinius leidinius ne tik iš skyriaus, bet ir Nacionalinès bibliotekos fondų. Bibliografinès informacijos skyriuje leidiniai išsinešti išduodami Seimo nariams, Seimo kanceliarijos darbuotojams, Nepriklausomybès akto signatarams. Kiti vartotojai - Europos Parlamento nariai, politinių partijų nariai, valstybès tarnautojai, akademikai, studentai ir kiti, norintys pasinaudoti skyriuje sukauptais leidiniais, juos gali skaityti tik skaitykloje. Skyriuje kaupiamos Seimo stenogramos (nuo 1920 m. - Steigiamojo Seimo, LTSR Aukščiausiosios Tarybos iki šių dienų); „Valstybès žinios“ (nuo 1993 m. iki šių dienų; taip pat „Laikinosios Vyriausybès žinios“, 1918-1920 m.; „Vyriausybès žinios“, 1923-1940 m.; LTSR Aukščiausiosios Tarybos žinios, 1940-1990 m.). Čia taip pat galima rasti pagrindinius Lietuvos ir užsienio periodinius leidinius, regioninès spaudos. Nuo 1989 metų skyriuje pradètas kaupti teminis archyvas Seimo darbui aktualiomis temomis, nuo 2004 m. lapkričio mèn. - Seimo narių straipsnių ir straipsnių apie juos lietuviškoje periodikoje archyvas.

Siekdamas geriau pažinti Seimo narių informacinius poreikius ir efektyviau juos tenkinti, skyrius atlieka jų informacinių poreikių tikslinimą. Tačiau išsamūs parlamentarų informacinių poreikių moksliniai tyrimai iki šiol nebuvo atliekami. 


\subsection{Lietuvos integrali biblioteku informacijos sistema - parla-} mentarų informaciniams poreikiams tenkinti

Vadovybės informacijos skyrius, kaip ir kiti Nacionalinès bibliotekos struktūriniai padaliniai, yra Lietuvos integralios bibliotekų informacijos sistemos dalis ir naudojasi to paties - LIBIS - pavadinimo programine įranga, kuri funkcionuoja daugelyje šalies bibliotekų ir muziejų. Tai reiškia, kad Lietuvos parlamentarams yra prieinami visi šios sistemos skaitmeninio turinio produktai: suskaitmeninti ir žiniatinklio elektroniniai ištekliai, kurie yra archyvuojami Nacionalinės bibliotekos talpyklose. Ypatingą reikšmę parlamentarams turi Lietuvos dienraščių ir kitų tęsiamųjų išteklių bibliografiniai ịrašai, saugomi Nacionalinès bibliografijos duomenų banke.

Parlamentarai taip pat gali naudotis Nacionalinès bibliotekos katalogu, Suvestiniu katalogu, nurodančiu šalies bibliotekose sukauptų tradicinès formos dokumentų: knygų, laikraščių, retų spaudinių, rankraščių adresus, bei portale www.epaveldas.lt skaityti senuosius laikraščius ir kitus dokumentus.

Be jau išvardytų elektroninių paslaugų, Nacionalinès bibliotekos Vadovybès informacijos skyrius vykdo papildomą Seimo bibliografini ir informacini aptarnavimą. Šiame skyriuje dirba 19 darbuotojų, ji sudaro trys padaliniai: Seimo aptarnavimo grupé, apžvalgų rengimo grupe ir duomenų bazių organizavimo grupè. Seimo aptarnavimo padalinio pagrindinis uždavinys - Seimo vadovybès ir Seimo narių, jų patarejjų, komitetų ir komisijų, kitų valstybės tarnautojų bibliografinis-informacinis aptarnavimas. Padalinio darbuotojai atsako $\mathfrak{i}$ temines, bibliografines ir faktografines užklausas, rengia bibliografinius sąrašus, užsienio spaudos bei temines spaudos apžvalgas.

Seimo aptarnavimo padalinys rengia Lietuvos spaudos apžvalgą (2 kartus per mėnesî), bibliografinę apžvalgą teisès klausimais (2 kartus per mènesį).

Apžvalgų rengimo padalinys kas savaitę rengia Lietuvos miestų ir rajonų spaudos apžvalgą ir Lietuvos partijų, judejimų, žinybų spaudos apžvalgą. 
Per mėnesị peržiūrima apie 1,5 tūkst. egzempliorių laikraščių. Nuo 1995 m. spalio mèn. ị skyriaus duomenų bazes įvedami miestų bei rajoninès spaudos straipsnių bibliografiniai įrašai. Nuo 1998 m. rugsejo mèn. daromos Seimo narių straipsnių bei straipsnių apie jų veiklą kopijos iš miestų, rajonų, partijų, žinybų spaudos.

Automatizuoto informacijos apdorojimo padalinys nuo $1994 \mathrm{~m}$. kuria Lietuvos spaudos straipsnių duomenų bazes aktualiomis Seimui, Prezidento kanceliarijai ir Vyriausybei temomis.

Skyrius koordinuoja savo veiklą su kitais Nacionalinès bibliotekos skyriais, Seimo kanceliarijos Parlamentinių tyrimų departamentu. Glaudžiai bendradarbiauja su kitomis respublikos bibliotekomis, informacinèmis tarnybomis, Estijos, Latvijos nacionalinių bibliotekų parlamentiniais skyriais.

\subsection{Seimo informacinė sistema - valdžios atvirumui visuomenei užtikrinti}

Kaip minèta įvadineje dalyje, demokratinès visuomenès privalumas - valdžios atvirumas visuomenei, atskaitingumas rinkejjams. Šiam principui įtvirtinti Seime yra įdiegtos ir tvarkomos trys valstybès informacinès sistemos: Teisès aktų informacinè sistema, Lietuvos Respublikos Seimo veiklos informacinè sistema ir Lietuvos Respublikos Seimo interneto portalo informacinè sistema. Teisès aktų informacinè sistema skirta centralizuotai kaupti ir tvarkyti duomenis apie priimtus ir įregistruotus teisès aktus ir teikti juos teisès aktų leidybos iniciatyvos teisę turintiems ar su teisèkūra susijusiems subjektams. Ši sistema leidžia visuomenei susipažinti su Seimo jau priimtais teisès aktais ar jų projektais. Seimo veiklos informacinè sistema renka, kaupia ir sistemina duomenis apie Lietuvos Respublikos teisès aktus ir jų projektus, Europos Sąungos ir jos šalių narių teisès aktus, Seimo ir Seimo kanceliarijos pavedimų formavimą bei vykdymą, Seime vykstančius posèdžius, Seimo kanceliarijos veiklą ir kt. Lietuvos Respublikos Seimo interneto portalo informa- 
cinè sistema skirta kaupti ir saugoti Seimo veiklos duomenis, pristatyti teisèkūros procesą ir teisès aktus. ${ }^{29}$

\section{Išvados}

1. Žiniomis ir informacija grịsti sprendimai užtikrina, kad parlamento darbas būtų veiksmingas. Aprūpintas nepriklausoma, nešališka ir objektyvia informacija parlamentas yra pajègūs atlikti savo pagrindines funkcijas teisèkūros procese, vykdyti parlamentinę kontrolę ir atstovauti rinkejjams. Aprūpintas reikalinga informacija parlamentas igyja daugiau galių politiniuose procesuose, yra mažiau priklausomas nuo vykdomosios valdžios.

2. Pertvarkant parlamentinès bibliotekas pagal inovatyvias tendencijas ir technologijų plètrą, svarbu atsižvelgti ir ì parlamentarų informacinius poreikius, kurie yra dinamiški ir sąlygojami daugelio veiksnių. Lietuvos parlamentaru informacines reikmes, vykdydamas apklausas, tiria Seimo kanceliarijos Parlamentinių tyrimų departamentas, tačiau išsamūs moksliniai tyrimai šioje srityje nebuvo atliekami.

3. Lietuvos parlamentarų informacinị aprūpinimą vykdo Seimo ir Nacionalinès bibliotekos padaliniai, pasitelkdami šioms funkcijoms Seimo informacinę sistemą ir LIBIS. Galima tvirtinti, kad šių dviejų institucijų veikla teikiant parlamentarams reikalingiausią informaciją sprendimų prièmimui yra koordinuojama, tačiau išsamiai šių institucijų sąveika nebuvo tyrinèta.

29 Valstybinio audito ataskaita „Lietuvos Respublikos Seimo kanceliarijos informacinès sistemos bendrosios kontrolés vertinimas “. $2009 \mathrm{~m}$. sausio $30 \mathrm{~d}$. 


\title{
INFORMATION PROVIDENCE FOR DEPUTIES - THE MEANS TO DEVELOP DEMOCRACY
}

\author{
Regina Varnienė-Janssen, Aurelija Vernickaite்
}

\section{Summary}

Keywords: information needs; information providence arba provision of information; decision making; parliamentary library.

Access to and the dissemination of European content in global networks is one of the priorities of the Lisbon Strategy, utilizing all available digital technological abilities and creating a common European information network, which allows for the implementation of the idea of a unified Europe. The problem of the provision of information to the government and its transparency is relevant within the context of the creation of a unified and transparent Europe. Decisions based on knowledge and information ensures the work of the parliament is effective. A parliament provided with independent, unbiased and objective information is capable of carrying out its main functions the process of legislation, implement parliamentary control and represent voters; a parliament provided with necessary information acquires more control in the political process and is less dependant upon the executive authority. This publication mostly deals with the role of information in decision-making, taking into consideration studies conducted on the informational requirements of parliamentarians and the information provided to them, and acquaints the reader with the state of provided information to Lithuania's parliamentarians.

The provision of information to Lithuania's parliamentarians is executed by subdivisions of the Seimas of the Republic of Lithuania and Martynas Mažvydas National Library of Lithuania, utilizing the information system of the Seimas of the Republic of Lithuania and LIBIS for these functions. It can be stated that the operation of these two institutions, providing parliamentarians with the most necessary information for decision-making, is coordinated, however the interaction of these institutions has not been studied more comprehensively. When reforming parliamentary libraries according to innovative trends and technological growth, it is important to take into consideration the informational requirements of parliamentarians, which are dynamic and subject to many factors. The Seimas of the Republic of Lithuania Parliamentarian research department analyzes questionnaires carried out on the informational needs of Lithuania's parliamentarians, however comprehensive scientific studies have not been performed. 